\title{
Characterization and evaluation properties of ceramic proppants used in the extraction of the unconventional hydrocarbons
}

\author{
Charakterystyka i ocena ceramicznych propantów \\ wykorzystywanych w procesie wydobycia \\ węglowodorów niekonwencjonalnych
}

\author{
PAWEK WIŚNIEWSKI \\ MATEUSZ KONRAD KORALNIK \\ MARCIN MALEK \\ JOANNA SZYMAŃSKA \\ JAROS $Ł A W$ MIZERA \\ KRZYSZTOF JAN KURZYDŁOWSKI *
}

\author{
DOI: 10.17814/mechanik.2016.5-6.65 \\ Międzynarodowa Konferencja IMT 2016
}

This paper presents the study of the experimental ceramic proppants. Examined samples were obtained by mechanical granulation method. After granulation process proppants had been sintered in $1550^{\circ} \mathrm{C}$. Investigated proppants were characterized by Scanning Electron microscope (SEM) with Electron Diffraction Spectroscope (EDS) and Light Microscope (LM). During the research solubility in acids, sphericity coefficient, turbidity, moisture were determined. Moreover bulk density was conducted. The result shows that new ceramic proppants are acceptable for industry and meet their requirements.

KEYWORDS: ceramic proppants, shale gas, mechanical granulation

Niniejsza praca prezentuje wyniki badań eksperymentalnych propantów ceramicznych. Badane próbki były otrzymane w wyniku procesu granulacji mechanicznej a następnie spieczone w temperaturze $1550{ }^{\circ} \mathrm{C}$. Próbki poddano obserwacjom mikroskopowym z wykorzystaniem elektronowego mikroskopu skaningowego (SEM), z przystawką EDS, oraz mikroskopu świetlnego (LM). W trakcie badań określono: współczynnik kulistości, mętność, wilgotność oraz odporność na rozpuszczanie w kwasach. Dodatkowo wyznaczono gęstość nasypową.

SŁOWA KLUCZOWE: propanty ceramiczne, gaz łupkowy, granulacja mechaniczna

Shale gas is an alternative source to natural gas. It is getting more economically reasonable to explore unconventional hydrocarbons such as shale gas [1]. Shell gas extraction is increasing year by year. The gas is extract from the deposits by hydraulic fracturing method. In this process fracturing fluid is forced into the shale and it causes a lot of micro cracks in the rock.

Fracturing fluid consist of many chemical substances affecting on extraction process. Furthermore, it is composed

\footnotetext{
* Dr inż. Paweł Wiśniewski, mgr inż. Mateusz Konrad Koralnik (mateusz.koralnik@gmail.com), mgr inż. Joanna Szymańska, prof. nadzw. dr hab. inż. Jarosław Mizera, prof. zw. dr hab. inż. Krzysztof Kurzydłowski - Wydział Inżynierii Materiałowej, Politechnika Warszawska
}

of fracturing sand or ceramic proppants $[2 \div 3]$. It prevents collapse of the bad and allows the gas flow $[4 \div 6]$.

\section{Methodology}

Ceramic proppants based on Polish raw materials were investigated. The samples were obtained by mechanical synthesis. After preparation process proppants were sintered at $1550^{\circ} \mathrm{C}$.

In order to identify the morphology and chemical composition of analyzed samples SEM observation with EDS measurement were conducted. Study were carried out on Hitachi Phenom proX desktop SEM (5 kV and SE detector) combined with EDS detector.

Important parameter of ceramic proppants is their shape. This feature was evolved by using LM. During microscopic observation the samples were contoured and the sphericity coefficient was defined by stereology program (MicroMeter 1.04).

Other parameters such as: turbidity, moisture content, bulk density and solubility in acids were obtained in accordance to Polish Standard PN-EN ISO 13503-2. Researches were carried out in laboratory conditions with use of certified equipment.

\section{Results and discussion}

The results of morphology characterization are shown in Fig. 1 and 2. Proppant exhibits geometry nearly by spherical. There are few pores and unevenness on the surface of the investigated sample. Using higher magnification in Fig. 2 was observed that the proppant surface is strong expanded. There are many pores and discontinuities.

Chemical composition of the analyzed ceramic proppant was determined by EDS. The spectrum with the picture of examined area shown in the Fig. 3.

In the analyzed sample aluminum, silicon, oxygen and nitrogen were detected by EDS analysis. It confirms that the main components were aluminum and silicon oxides.

Observation results from LM shown in Fig. 4. The shape and size of examined samples is differentiated. Their surface is irregular. The sphericity coefficient was defined by stereology program. The shape of the proppants shown in Fig. 4 was contoured and sent to the MicroMeter 1.04 soft- 
ware. Fig. 5 shows the image of the analyzed samples and number of particles used in sphericity factor calculations.

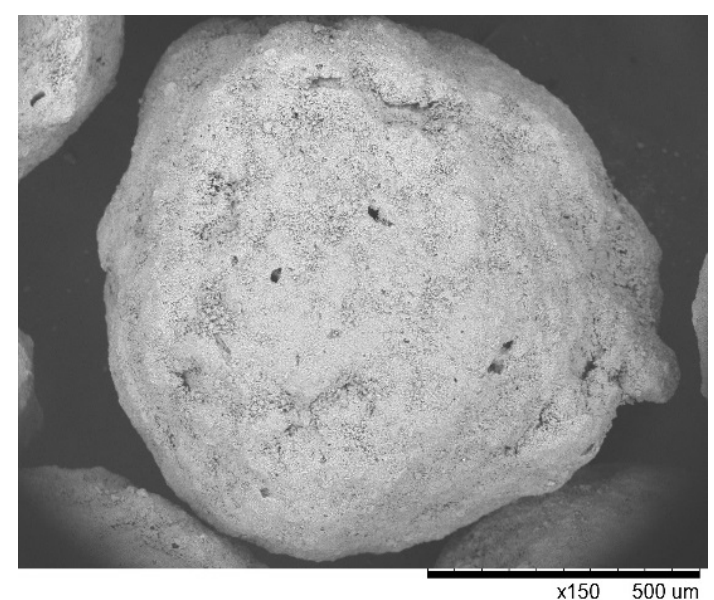

Fig. 1. SEM image of ceramic proppants at magnification of $150 \times$

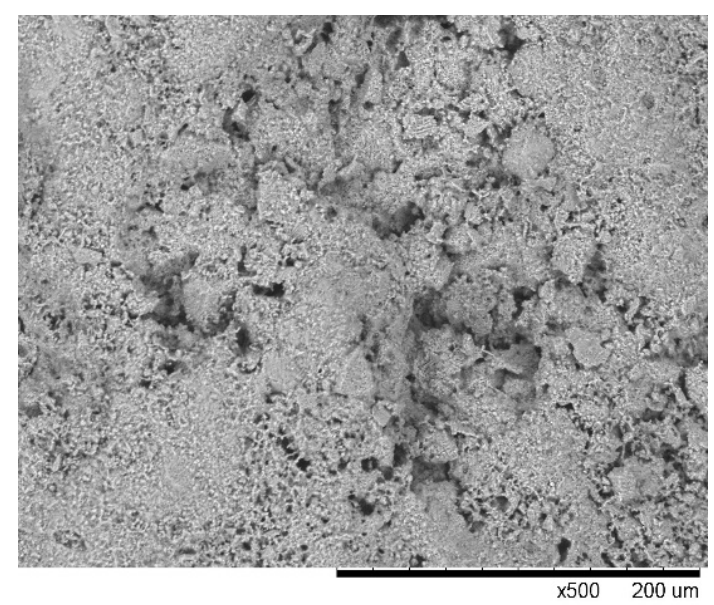

Fig. 2. SEM image of ceramic proppants at magnification of $500 x$

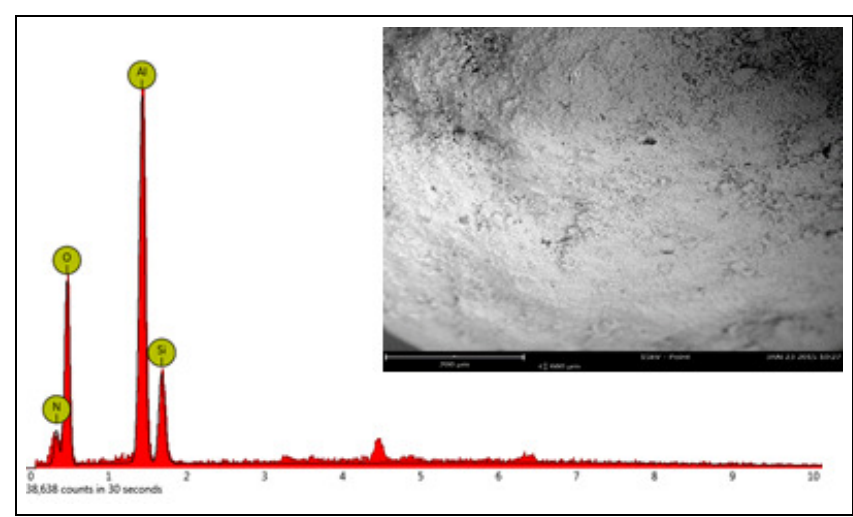

Fig. 3. The EDS spectrum of the analyzed proppants

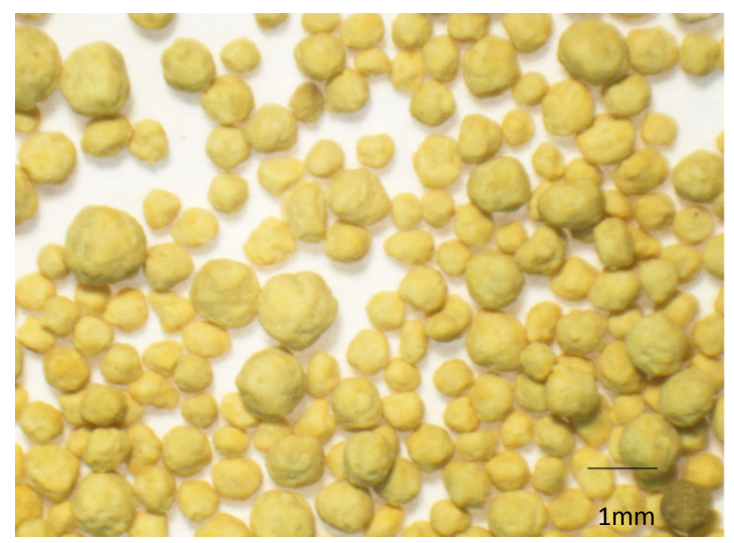

Fig. 4. LM micrograph of ceramic proppants

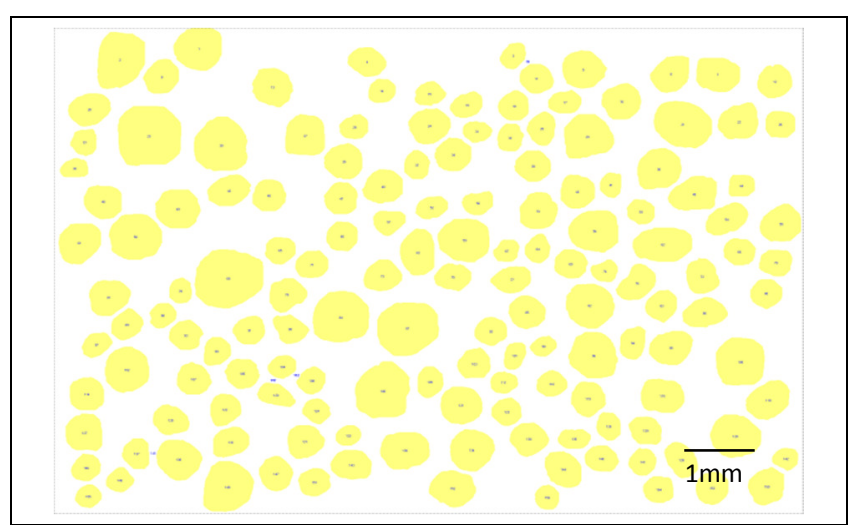

Fig. 5. Sphericity analysis picture of the proppants - number of used particles

The results of measurements of turbidity, impregnability, sphericity, bulk density and solubility in acids were shown in the table. The measurements were conducted according to Polish Standard PN-EN ISO 13503-2.

\section{TABLE. Properties of analyzed proppants according to PN-EN ISO 13503-2}

\begin{tabular}{|l|c|}
\hline Sphericity coefficient & 0.84 \\
\hline Bulk density, g/cm² & 1.53 \\
\hline Turbidity NTU & 171.00 \\
\hline Solubility in acids, \% & 0.60 \\
\hline Moisture content, \% & 0.08 \\
\hline
\end{tabular}

The sphericity coefficient is about 0.84 . Suggested value of this factor is about 0.90 . Measured bulk density was $1.53 \mathrm{~g} / \mathrm{cm}^{2}$. Solubility test was carried out in $\mathrm{HCl}$ and $\mathrm{HF}$ acids solution. The value of solubility is about $0.6 \%$. Turbidity test shown that investigated proppants are prone to disintegration in water. The NTU value is about 171 units.

\section{Conclusions}

Investigated ceramic proppants are characterized by high sphericity factor. There is observed a big value of turbidity, for analyzed samples it was $171.00 \mathrm{NTU}$. It is too high to use these ceramic proppants in hydraulic fracturing process. This parameter should be below 60 NTU units. For use in shale gas extraction the properties of analyzed samples should be improved in accordance to Polish Standard.

This work was financially supported by Faculty of Material Science and Engineering of Warsaw University of Technology.

\section{LITERATURE}

1. De Silva P.N.K., Simons S.J.R., Stevens P. „Economic impact analysis of natural gas development and the policy implications". Energy Policy. Vol. 88 (2016): pp. 639 651.

2. Zhao J.Z., Liu Z.L., Li Y.M. „Preparation and characterization of low-density mullite-based ceramic proppant by a dynamic sintering method". Materials Letters. Vol. 152 (2015): pp. 72 $\div 75$.

3. Tong Y.P., Wang H.X., Wang Q. „Preparation of a New Fracture Ceramic Proppant". Applied Mechanics and Materials. Vol.

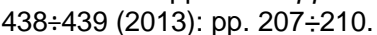

4. Masoomi R., Bassey I., Viktorovich D., Dehghani H. „Analysis of proppant hydraulic fracturing in a sand oil reservoir in southwest of Iran". International Journal of Engineering and Technology. Vol. 7, No. 5 (2015): pp. 1598 $\div 1609$.

5. Wang D., Yan C., Wang H., Qiu X. „The research of oil-shaledreg in preparing petroleum proppant". Advanced Materials Re-

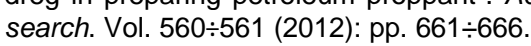

6. Zhou D., Zheng P., He P. „Hydraulic fracture propagation direction during volume fracturing in unconventional reservoirs". Journal of Petroleum Science and Engineering". Vol. 141 (2016): pp. $82 \div 89$. 